\title{
Harvest Time and Storage Condition Affect Germination, Moisture, Abscisic Acid, and Indoleacetic Acid in Pecan
}

\author{
Pedro Jover ${ }^{1}$ \\ Instituto Nacional De Technologia Agropecuaria (INTA), Centro Regional \\ Chaco-Formosa, Formosa, Argentina \\ Frank B. Matta ${ }^{2,4}$ \\ Department of Plant and Soil Sciences, Mississippi State University, 117 \\ Dorman Hall, PO Box 9555, Mississippi State, MS 39762
}

Fawad S. Shah
Department of Agriculture, Seed Program, Yakima, WA 98902

Additional index words. Carya illinoensis, plant growth regulators, pecan nuts

\begin{abstract}
Moisture percentage, free abscisic acid, and total indoleacetic acid (IAA) content were determined at shuck-split in 'Hughes' and 'Owens' pecan kernels (nuts harvested from the tree), immediately after harvest from the ground, and after subsequent storage periods of 45, 90, and $135 \mathrm{~d}$ at $3{ }^{\circ} \mathrm{C}$ or $10{ }^{\circ} \mathrm{C}$. In 'Hughes', seed germination increased when nuts were harvested from the tree compared with germination of nuts harvested from the ground or nonstratified and stratified nuts. Germination of nuts harvested from the ground did not differ from germination of nuts stored at $3{ }^{\circ} \mathrm{C}$ in moist media for 45,90 , or $135 \mathrm{~d}$. Significant positive correlation between germination of 'Hughes' and 'Owens' and moisture percentage was observed. There was no relationship between abscisic acid levels and germination in either cultivar. However, there was a significant correlation between germination of 'Hughes' and IAA. Germination of 'Owens' did not correlate with IAA levels.
\end{abstract}

Lack of uniform and poor pecan seed germination is oftentimes a problem for nurserymen producing pecan rootstocks for grafting. Pecan germination requirements have been investigated extensively. Previous findings show that stratification (chilling at $0-3{ }^{\circ} \mathrm{C}$ in moist media) enhanced germination of pecan (Knox and Smith, 1981). Laiche (1976) reported that pecan nuts stored dry at ambient temperature produced fewer seedlings than stratified nuts. O'Barr (1976) reported that stratification did not increase germination compared with nuts harvested from the ground, and suggested the ground harvested nuts were high in moisture and had not dried sufficiently. Previous research indicated that water inhibition alone increased germination percentage of 'Riverside' pecan (Knox and Smith, 1981). Gosling (1989) reported that

\footnotetext{
Received for publication 29 Aug. 2005. Accepted for publication 24 Apr. 2006. Research was conducted at the Physiology Laboratory, Department of Plant and Soil Sciences, Mississippi State University, Mississippi State, MS 39762. Use of trade names does not imply endorsement of the products named nor criticism of similar ones not named.

${ }^{1}$ Research Scientist.

${ }^{2}$ Professor of Horticulture.

${ }^{3}$ Seed Program Manager.

${ }^{4}$ To whom correspondence should be addressed;
} e-mailfmatta@pss.msstated.edu. drying and storing Quercus robur acorns significantly reduced germination percentages.

The mechanisms controlling germination of pecan have not been fully investigated. Desiccation may affect the flow of germination, suppressing substances to the embryo, or alter the sensitivity of the embryo to suppressive or promotive substances (Kermode et al., 1986). Gibberellins are known to play an important role in germination, especially in the activation of reserve food mobilization and enzyme induction (Hartman, et al., 1990). Abscisic acid (ABA) levels in developing pecan nuts were reported by Wood (1984). Endogenous levels of growth regulators in pecan seed at harvest and in subsequent storage have not been reported. There is no information on the changes of ABA and IAA in pecan seed as influenced by storage condition or time in storage. In walnut (Juglans regia L.), kernel extracts showed evidence of an auxinlike substance and an inhibitor, presumably ABA. This inhibitor decreased in concentration during moist chilling (Martin et al., 1969). A negative relationship between ABA levels and time in stratification was found for $J$. regia (Martin et al., 1969) and Prunus domestica L. (Lin and Boe, 1972). Levels of ABA in pecan kernels as influenced by time in storage under given conditions, such as stratification, have not been reported. Previous work with 'Stuart' pecan showed that germination increased with stratification and the response was ge- notype dependent. Northern cultures showed a greater response to stratification than the southern cultures (Sparks et al., 1974).

Seed treatment methods to enhance germination, reduce germination time, and increase uniformity of germination may be developed by understanding the role of growth regulators in pecan germination. Such treatment methods would be advantageous to nurserymen in the production of uniform pecan rootstocks of adequate caliper for grafting in a shorter time period. This report presents the influence of seed moisture, endogenous ABA and IAA, time of harvest, and storage duration (stratified vs. unstratified) on pecan seed germination.

\section{Methods and Materials}

Pecan nuts of 'Hughes' and 'Owens' were harvested by hand from the tree at shuck-split and about 2 weeks later from the ground, and were analyzed without further treatment. Additional nuts collected from the ground were stored in plastic flats $(7.5 \times 30 \times 45 \mathrm{~cm})$ for 45,90 , and $135 \mathrm{~d}$ at either $3{ }^{\circ} \mathrm{C}$ or $10^{\circ} \mathrm{C}$. Flats stored at $10{ }^{\circ} \mathrm{C}$ contained no medium and were held at $45 \%$ relative humidity $(\mathrm{RH})$. Flats stored at $3{ }^{\circ} \mathrm{C}$ were filled with a mixture of 1 vermiculite, 0.5 perlite, and 1 peat moss (volume/volume) and were kept moist. Nut moisture percentage, free ABA, and total IAA were determined at shuck-split (nuts harvested from the tree), immediately after harvest from the ground, and at subsequent storage periods of 45,90 , and $135 \mathrm{~d}$ at $3{ }^{\circ} \mathrm{C}$ or $10{ }^{\circ} \mathrm{C}$. Germination, the appearance of the radicle through the shell, was determined on four replicates of 30 seeds each per treatment per cultivar, randomly selected from each plastic tray. Nuts were germinated in a chamber at $30^{\circ} \mathrm{C}$ with $8 \mathrm{~h}$ dark and $16 \mathrm{~h}$ fluorescent light. To determine moisture percentage, ABA and IAA levels, randomly selected sample of 15 nuts per replicate per treatment was used. The experimental design was a completely randomized design with eight treatments and four replications. Data were analyzed as a means model according to Milliken and Johnson (1984). Means were separated by least significant difference at a $5 \%$ level of probability. In addition, linear contrasts were used to investigate linear and quadratic effects of stratification time and nonstratification time.

A random sample of 15 seeds was shelled and ground with mortar and pestle. From this sample, $0.3 \mathrm{~g}$ fresh material was removed and extracted for $2 \mathrm{~d}$ at $4{ }^{\circ} \mathrm{C}$ with $3 \mathrm{~mL}$ cold methanol containing $20 \mathrm{mg} \cdot \mathrm{L}^{-1}$ of butyl hydroxytoluene (Weiler, 1980). The extract was left for 4 hours at $4{ }^{\circ} \mathrm{C}$, then centrifuged at $4500 \mathrm{~g}$ for $15 \mathrm{~min}$ at $4.5^{\circ} \mathrm{C}$. The supernatant was kept in the freezer at $-15^{\circ} \mathrm{C}$ until purification. The methanol was evaporated under nitrogen, hydrochloric acid was added to obtain a $\mathrm{pH}$ of 3 , and the extract was partitioned with ethyl acetate following the method used by Wood (1983). The ethyl acetate fraction was retained for analysis and the final eluate volume was adjusted to 
$3 \mathrm{~mL}$ for all samples. Ten microliters from each sample were used to determine free ABA levels by immunoassay. A stock solution $(1 \mathrm{mM})$ of $\mathrm{ABA}$ ( \pm cis-trans isomer, $99 \%$; Sigma Chemical Company, St. Louis, Mo., USA) in methanol was prepared and three independent sets of recommended dilutions $(0.05,0.1,0.5,2.0$, and $100 \mathrm{pmol} \mathrm{ABA} /$ assay $)$ were used as standards.

The IAA extraction was performed under indirect light and vials were covered with aluminum foil. Before the immunoassay of IAA, $0.4 \mathrm{~mL}$ of each sample extract was dried under nitrogen, and excess diazomethane was added to transform the IAA to its methyl ester. The diazomethane was then evaporated under nitrogen, and $0.4 \mathrm{~mL}$ tris buffered saline $(\mathrm{pH}, 7.5)$ solution was added. One hundred microliters of this extract was assayed. A stock solution (10 $\mathrm{mM}$ ) of IAA in methanol was prepared. Three samples of $0.4 \mathrm{~mL}$ each were evaporated under nitrogen and methylated with an excess of diazomethane. The final volume was adjusted to $0.4 \mathrm{~mL}$ with methanol. For each sample, recommended dilutions $(0,1$, $5,20,50$, and 500 pmol IAA/assay) were used as standards.

Levels of endogenous ABA and IAA in extracts were determined using immunoassay test kits (Phytodetek ${ }^{\text {TM }}$-IAA; Idetek, Inc., San Bruno, Calif., USA). The assay used the competitive protein binding method. The antibody-coated microwell was filled with alkaline phosphates (tracer) and the plant extract. The hormone in the plant sample competed with the tracer for antibody binding sites. After incubation at $4{ }^{\circ} \mathrm{C}$ for $3 \mathrm{~h}$, the tracer was washed out. The substrate (p-nitrophenyl phosphenyl) was then added. this bound to the tracer and produced a change in coloration. After incubation at $37^{\circ} \mathrm{C}$ for $1 \mathrm{~h}$, the Automated Microplate Reader (model EL 309; Bio-Tek Instruments, Inc., Winooski, Vt.) was used to read absorbance at $405 \mathrm{~nm}$ (single wavelength). A standard curve was drawn, plotting percentage of binding as a function of hormone concentration. This curve was used to determine hormone concentration in the sample (Mertens et al., 1985; Weiler, 1980; Weiler et al., 1981).

\section{Results and Discussion}

In 'Hughes', germination was greater when nuts were harvested from the tree compared with all other treatments (Table 1). Germination of nuts harvested from the ground did not differ from germination percentage of nuts stored at $3{ }^{\circ} \mathrm{C}$ in moist media for 45,90 , or $135 \mathrm{~d}$ (stratified nuts). In addition, germination percentage of nuts stored at $3{ }^{\circ} \mathrm{C}$ did not change with days in storage, as indicated by orthogonal contrasts. Furthermore, nuts stored at $3{ }^{\circ} \mathrm{C}$ in moist media had greater germination percentages than unstratified nuts stored at $10^{\circ} \mathrm{C}$ regardless of days in storage (control). There was a linear decrease in germination of nuts stored at $10{ }^{\circ} \mathrm{C}$ with storage time.

In 'Owens', there was a linear decrease in germination percentage of nuts stored at $3{ }^{\circ} \mathrm{C}$ with storage time (Table 1). A reduction in germination with time at $3{ }^{\circ} \mathrm{C}$ was not expected, because previous work showed that length (weeks) of stratification increased percentage germination (Sparks et al., 1974). Madden and Tisdale (1975) indicated that response to stratification varied with genotype. Northern cultivars showed greater response to stratification than southern cultivars.

In 'Hughes', there was a linear increase in moisture percentage of nuts stored at $3{ }^{\circ} \mathrm{C}$ with time in storage. Moisture percentage of nuts stored at $10^{\circ} \mathrm{C}$ did not change with days in storage as indicated by orthogonal contrasts. Moisture percentage of nuts harvest from the ground and analyzed immediately, and nuts stored at $10{ }^{\circ} \mathrm{C}$ and $45 \% \mathrm{RH}$ and stored for 45,90 , or $135 \mathrm{~d}$ (control) did not differ. However, nuts harvested from the tree and analyzed immediately had greater moisture percentage compared with nuts harvested from the ground (Table 1). Nut moisture was shown to be a factor that influenced germination as previously reported by Knox and Smith (1981). Previous research indicated that water imbibition alone increased germination percentage of 'Riverside' pecan (Knox and Smith, 1981). Gosling (1989) reported that drying and storing $Q$. robur acorns significantly reduced germination percentages.

Levels of ABA in 'Hughes' pecan seed ranged from $377 \mathrm{ng} \cdot \mathrm{g}^{-1}$ dry weight to 4175 ng. $\mathrm{g}^{-1}$ dry weight (Table 1 ). Nuts stored at $3{ }^{\circ} \mathrm{C}$ in moist medium had the highest amount of free $\mathrm{ABA}$ compared with the remaining treatments. However, orthogonal contrasts indicated that $\mathrm{ABA}$ levels did not change with days in storage at either $3{ }^{\circ} \mathrm{C}$ or $10{ }^{\circ} \mathrm{C}$. Levels of free ABA in this study were greater than those reported by Wood (1984), who found 20 to $40 \mathrm{ng} \cdot \mathrm{g}^{-1} \mathrm{kernel}$ dry weight at the same stage. This disagreement may be the result of differences in cultivars ('Moneymaker' vs. 'Hughes' and 'Owens'), ABA detection techniques used (gas chromatography vs. enzyme immunoassay), or effects of location and year. Correlation analysis showed that there was no relationship between ABA levels and germination. In general, $A B A$ is reported to be a germination inhibitor, and the balance between $\mathrm{ABA}$ and gibberellic acid (GA) is critical in germination (Hartman et al., 1990). The levels of GA were not determined in this study. Levels of ABA in pecan kernels as influenced by time in storage under given conditions have not been reported. A negative relationship between ABA levels and time in stratification has been reported for $J$. regia (Martin et al., 1969) and P. domestica (Lin and Boe, 1972). Balboa-Zavala and Dennis (1977) also observed a decline of free ABA with time in stratification for embryonic axes and seed coasts of apple seeds. Dennis et al. (1978) found that free ABA levels ranged from 32 to $1235 \mathrm{mg} \cdot \mathrm{g}^{-1}$ fresh weight, depending on Pyrus species. It was anticipated that ABA could decrease in storage at a low temperature $\left(3^{\circ} \mathrm{C}\right)$. However, ABA levels were lower in unstratified nuts. In 'Owens', free ABA content did not change with days in storage at either $3{ }^{\circ} \mathrm{C}$ or $10^{\circ} \mathrm{C}$ as indicated by orthogonal contrasts. ABA content did not differ

Table 1. Effect of harvest time and storage condition on percentage moisture, percentage germination, ABA, and IAA levels in 'Hughes' and 'Owens' pecan.

\begin{tabular}{|c|c|c|c|c|c|c|c|c|}
\hline \multirow[b]{3}{*}{ Seed treatment } & \multicolumn{8}{|c|}{ Cultivar } \\
\hline & \multicolumn{2}{|c|}{ Moisture, \% } & \multicolumn{2}{|c|}{ Germination, $\%$} & \multicolumn{2}{|c|}{ ABA, ng. $g^{-1}$ dry weight } & \multicolumn{2}{|c|}{ IAA, ng. ${ }^{-1}$ dry weight } \\
\hline & Hughes & Owens & Hughes & Owens & Hughes & Owens & Hughes & Owens \\
\hline \multicolumn{9}{|l|}{ Harvested from } \\
\hline Tree & $34 \mathrm{c}^{\mathrm{y}}$ & $32 \mathrm{c}$ & $93 \mathrm{a}$ & $61 \mathrm{a}$ & $1377 \mathrm{c}$ & $650 \mathrm{~b}$ & $265 \mathrm{a}$ & $55 \mathrm{bc}$ \\
\hline Ground (not stored) & $8 \mathrm{~d}$ & $6 \mathrm{~d}$ & $56 \mathrm{~b}$ & $61 \mathrm{a}$ & $2400 \mathrm{~cd}$ & $2801 \mathrm{ab}$ & $65 \mathrm{~b}$ & $181 \mathrm{bc}$ \\
\hline \multicolumn{9}{|l|}{ Stratified, d } \\
\hline 45 & $50 \mathrm{~b}$ & $39 \mathrm{~b}$ & $64 \mathrm{~b}$ & $64 \mathrm{a}$ & $4175 \mathrm{a}$ & $2405 \mathrm{ab}$ & $223 \mathrm{a}$ & $774 \mathrm{a}$ \\
\hline 90 & $71 \mathrm{a}$ & $58 \mathrm{a}$ & $66 \mathrm{~b}$ & $51 \mathrm{ab}$ & $3717 \mathrm{ab}$ & $3088 \mathrm{a}$ & $24 \mathrm{~b}$ & $37 \mathrm{c}$ \\
\hline 135 & $72 \mathrm{a}$ & $55 \mathrm{a}$ & $69 \mathrm{~b}$ & $40 \mathrm{bc}$ & $2757 \mathrm{bc}$ & $1996 \mathrm{ab}$ & $22 \mathrm{~b}$ & $34 \mathrm{c}$ \\
\hline Significance $^{z}$ & $\mathrm{~L}$ & $\mathrm{~L}$ & NS & $\mathrm{L}$ & NS & NS & $\mathrm{L}$ & $\mathrm{L}$ \\
\hline \multicolumn{9}{|l|}{ Unstratified (control) } \\
\hline $45 \mathrm{~d}$ & $13 \mathrm{~d}$ & $11 \mathrm{~d}$ & $42 \mathrm{c}$ & $52 \mathrm{ab}$ & $1817 \mathrm{~d}$ & $1579 \mathrm{~b}$ & $39 \mathrm{~b}$ & $233 \mathrm{~b}$ \\
\hline $90 \mathrm{~d}$ & $12 \mathrm{~d}$ & $8 \mathrm{~d}$ & $32 \mathrm{c}$ & $38 \mathrm{bc}$ & $1555 \mathrm{c}$ & $1519 a b$ & $7 \mathrm{~b}$ & $36 \mathrm{c}$ \\
\hline $135 \mathrm{~d}$ & $11 \mathrm{~d}$ & $9 \mathrm{~d}$ & $10 \mathrm{~d}$ & $28 \mathrm{c}$ & $1382 \mathrm{c}$ & $1259 \mathrm{ab}$ & $7 \mathrm{~b}$ & $31 \mathrm{c}$ \\
\hline Significance & NS & NS & $\mathrm{L}$ & $\mathrm{L}$ & NS & NS & NS & NS \\
\hline LSD $(0.05)$ & 6 & 4 & 13 & 15.8 & 1388 & 2167.7 & 115 & 187.9 \\
\hline
\end{tabular}

${ }^{\mathrm{z}}$ Linear (L) and quadratic (Q) effects of stratification and nonstratification time.

${ }^{\mathrm{y}}$ Means separated by the least significant difference test (LSD) at 5\% level of probability. Means with the same letter do not differ.

${ }^{\mathrm{N}}$ Nonsignificant. 
between nuts harvested from the tree and nuts harvested from the grounds (Table 1). As with 'Hughes', no correlation was found between germination of 'Owens' nuts and ABA.

In 'Hughes', mean levels of IAA ranged from a minimum of $7.0 \mathrm{ng} \cdot \mathrm{g}^{-1}$ dry wt. to a maximum of $265 \mathrm{ng} \cdot \mathrm{g}^{-1}$ dry weight. Total IAA was higher in nuts harvested from the tree compared with nuts harvested from the ground. In addition, there was a linear decrease in IAA of nuts stored in $3{ }^{\circ} \mathrm{C}$ with storage time. However, IAA of nuts stored at $10^{\circ} \mathrm{C}$ did not change with days in storage, as indicated by orthogonal contrasts. Correlation analysis showed that there was a significant correlation $(r=056, P<0.05)$ between germination of 'Hughes' pecan and IAA content. Published data of total IAA levels in several species are usually lower than those reported in this study. For instance, Hopping and Bukovac (1975) found that total IAA level in $P$. cerasus seeds was lower at the end of fruit development (less that $500 \mathrm{ng} \cdot \mathrm{g}^{-1}$ dry weight) compared with higher levels at $21 \mathrm{~d}$ and $49 \mathrm{~d}$ after anthesis (more than $1500 \mathrm{ng} \cdot \mathrm{g}^{-1}$ dry weight). Several patterns of IAA levels were found in different species; however, the total IAA pattern of pecan nuts obtained in this study tended to agree with that of nondormant seeds.

In 'Owens', IAA levels ranged from 31 to $774 \mathrm{ng} \cdot \mathrm{g}^{-1}$ dry weight. Total IAA levels did not differ between nuts harvested from the tree compared to nuts harvested from the ground and were $55 \mathrm{ng} \cdot \mathrm{g}^{-1}$ dry weight and $181 \mathrm{ng} \cdot \mathrm{g}^{-1}$ dry weight, respectively. There was a linear decrease in IAA of nuts stored at $3{ }^{\circ} \mathrm{C}$ with storage time. However, IAA of nuts stored at $10{ }^{\circ} \mathrm{C}$ did not change with time in storage, as indicated by orthogonal contracts. Unlike in 'Hughes', no correlation was found between germination of 'Owens' nuts and IAA.
In conclusion, levels of ABA and IAA in pecan seed as influenced by storage condition and time in storage is presented for the first time in the literature. Results show that kernel moisture percentage was associated with increased germination of both pecan cultivars, but levels of ABA were not. Levels of IAA were correlated to germination in 'Hughes', but not 'Owens'. Monitoring the level of growth hormones in pecan seed of various cultivars during storage should be considered, because there was a definite cultivar response with respect to IAA.

\section{Literature Cited}

Balboa-Zavala, O. and F.G. Dennis, Jr. 1977. Abscisic acid and apple seed dormancy. J. Amer. Soc. Hort. Sci. 102:633-637.

Dennis, F.G., Jr., G.C. Martin, and J. MacMillan. 1978. Hormones in pear seeds. II Levels of abscisic acid, dihydrophaseic acid, and their metabolites in relation to seed dormancy in several Pyrus species. J. Amer. Soc. 103:314-317.

Gosling, P.G. 1989. The effect of drying Quercus robur acorns to different moisture contents, followed by storage, either with or without imbibition. Forestry 62:41-50.

Hartman, H.T., D.E. Kester, and F.T. Davies. 1990. Plant propagation. Principles and Practices. 5th ed. Prentice Hall, 647 p.

Hopping, M.E. and M.J. Bukovac. 1975. Endogenous plant growth substances in developing fruit of Prunus cerasus L. IV. Extractable auxin in the seed and pericarp. J. Amer. Soc. Hort. Sci. 100:399-401.

Kermode, A.R., J.D. Bewley, J. Dasgupta, and S. Mistra. 1986. The transition from seed development to germination: A key role for desiccation? HortScience 21:1113-1118.

Knox, C.A. and R.H. Smith. 1981. A method of rapid seed germination of pecan. Pecan Q. 15:23-24.

Laiche, A.J. Jr. 1976. Growth evaluation studies of one-year pecan seedlings of selected varieties, seed treatments and growing methods. Pecan South 3:356-358.

Lin, C.F. and A.A. Boe. 1972. Effects of some endogenous and exogenous growth regulators on plum seed dormancy. J. Amer. Soc. Hort. Sci. 97:41-44.

Madden, G.D. and H.W. Tisdale. 1975. Effects of chilling and stratification on nut germination of northern and southern pecan cultivars. HortScience 10:259-260.

Martin, G.C., M.I.R. Mason, and H.I. Forde 1969. Changes in endogenous growth substances in the embryos of Juglans regia during stratification. J. Amer. Soc. Hort. Sci. 94:13-17.

Mertens, R., J. Eberle, A. Arnscheidt, A. Ledebur, and E.W. Weiler. 1985. Monoclonal antibodies to plant growth regulators. II. Indole-3 acetic acid. Planta 166:389-393.

Milliken, A.G. and E.D. Johnson. 1984. Analysis of messy data, p. 2-3. VOL. I. Design experiments. Van Nostrand Reinhold Company, New York.

O’Barr, R.D. 1976. Germination study and seedling performance. Pecan South 3:424427.

Sparks, D., J.W. Chapman, and D.W. Lockwood. 1974. Stratification promotes germination. Pecan Q. 8:13.

Weiler, E.W. 1980. Radioimmunoassays for the differential and direct analysis of free and conjugated abscisic acid in plant extracts. Planta 148:262-272.

Weiler, E.W., P.S. Jourdan, and W. Conrad. 1981. Levels of indole-3-acetic acid in intact and decapitated coleoptiles as determined by a specific and highly sensitive solid-phase enzyme immunoassay. Planta 153:561-577.

Wood, B.W. 1983. Changes in indoleacetic acid, abscisic acid, gibberellins, and cytokinins during budbreak in pecan. J. Amer. Soc. Hort. Sci. 108:333-338.

Wood, B.W. 1984. Free and bound abscisic acid and free gibberellin-like substances in pecan kernel tissue during seed development. J. Amer. Soc. Hort. Sci. 109:626-629. 